\title{
Evaluation Of Skeletal Muscle Relaxant Activity Of Ethanol Extract Of Chromoleana Odorata
}

\author{
${ }^{1}$ Akash Kumar Shetty, ${ }^{1}$ Vinutha $N,{ }^{1}$ Sagar F. Udasimath ${ }^{1}$ Kalleshappa C.M, ${ }^{2 *}$ \\ Krupanidhi A.M, ${ }^{2}$ Akshara \\ ${ }^{1}$ Bapuji Institute of Engineering and Technology-Davangere-577004, India ${ }^{2}$ Bapuji Pharmacy College, \\ Davangere-577004, India
}

\begin{abstract}
Skeletal muscle relaxants are the agents that are used to treat both muscle spasm and spasticity, acting both as antispasmodic and antispasticity agents. Chromoleana odorata (C.Odorata) is traditionally used for various diseases because of its medicinal properties. The aim was to evaluate the skeletal muscle relaxant activity of the Ethanol extract of leaves of Chromoleana odoratain comparison with diazepam. The ethanol extract was given in Swiss Albino Mice at a dose of $50 \mathrm{mg} / \mathrm{kg}$ body weight and $100 \mathrm{mg} / \mathrm{kg}$ body weight. Skeletal muscle relaxant activity was assessed by using Rota-rod apparatus. The results are promising for further investigation of efficient skeletal muscle relaxant activity. The study may help in the development of cheap, effective and safe skeletal muscle relaxant drugs.
\end{abstract}

KEYWORDS: Rota-rod apparatus, Chromoleana odorata, Albino mice, Antispasticity,

\section{INTRODUCTION}

In modern days antispasmodic agents like cyclobenzaparin are used to treat musculoskeletal conditions. Antispasticity agents like dantrolene are used to relieve muscle hypertonicity. The side effects of antispasmodic agents and antispasticity agents cause them to be used with caution [1]. Previous reports have shown that 10$20 \%$ of adults suffer from insomnia [2]. The present study was conducted to evaluate the skeletal muscle relaxant activity of this plant. Chromolaena odorata (C.Odorata) is a species of flowering shrub in the sunflower family Asteraceae. It is native of North America, from Florida and Texasto Mexico and the Caribbean [1] and has been introduced to tropical Asia, West Africa, and parts of Australia. Their vernacular namesEnglish: Siam weed, Hindi: French: French weed: Kannada: Kammunist pacha. The plant is rapidly growing perennial herb.It is a multi-stemmed strub to $2.5 \mathrm{~m}$ (100 inches) tall in open areas. It has soft stem but the base of the shrub is woody. It can become up to $10 \mathrm{~m}$ tall. The plant is hairy and glandular the leaves give off a pungent, aromatic odour when crushed. The leaves are opposite, triangular to elliptical with serrated edges. Leaves are $4-10 \mathrm{~cm}$ long by $1-5 \mathrm{~cm}$ wide. The white to pale pink tubular flowers are in penicles of 10 to 35 flowers that form at the ends of branches. The seeds are achenes and are somewhat hairy.Chromolaena odorata(C.Odorata) is distributed in tropical and subtropical ares extending from west, central and southern Africa to India, Sri Lanka, China, Taiwan, Bangladesh, India (Western Ghats- in dry zones of South, Central and south Maharashtra Sahyadris), Myanmar and Srilanka[3]. Traditionally, Chromolaena odoratais used to treat azoospermia, diuretic, opthalmopathy, constipation[4] anti-inflammatory, analgesic and antipyretic [5]. The plant is also known to treat aphrodisiac, elephantiasis, eye infection, habitual abortion, sterility and laxative[6] and it is used for the treatment of cough, cold and fever [7,8]. The plant is also used to make toys due to its soft, light and flexible woods. A plant's medicinal value is due to the presence of some chemical substance that produces a physiological action on the Human body and therefore researchers always try to isolate these chemical substances from plants. C.Odoratais acknowledged for its medicinal properties so it's important to reveal other medicinal and phytochemical elements. The phytochemical compound contains polar and non-polar functional groups and therefore their solubility varies in different solvents. Many researchers have already carried out the preliminary phytochemical study of solubility of phytochemicals in their estimation process. In the present investigation, skeletal muscle relaxant activity was carried out.

\section{MATERIAL AND METHODS}

Collection of Plant material

Healthy leaves of Chromoleana Odorata were collected from the road side of Ampar village, Kundapur 'taluka' Udupi 'district', Karnataka, India.. The plant was authenticated (Voucher specimen: 
108/C.odorata) by taxonomist Dr P.M Shivkumar, department of botany DRM Science college, Kuvempu University, Davanagere, India, Dried leaves were powdered to get a coarse powder.

\section{Preparation of leaf extract}

Leaves were dried for one week at room temperature (in shade). Dried leaves were grinded in a blender to fine particles.

\section{Hot Extraction method}

Crude leaf extract was prepared by Soxhlet extraction method. Range Three polar to non-polar solvents was selected for the extraction, namely Ethanol, chloroform, petroleum ether, The $85 \mathrm{gm}$ of dried finely grinded powder was uniformly packed into thimble and phytochemicals were extracted with $750 \mathrm{ml}$ of three mentioned solvents separately. The extraction was carried out for 12 hours. Later extract was concentrated by keeping it on water bath for $50^{\circ}$ to $60^{\circ} \mathrm{C}$ and stored at $0^{\circ} \mathrm{C}$ for further study.

\section{Phytochemical screening}

Phytochemical investigation on leaf extracts of Chromoleana Odorata was carried out for the presence of alkaloids, carbohydrates, glycosides, steroids, flavonoids, coumarins, saponins, fatty acids, tannins, protein, amino acids, gum, mucilage, terpenoids, anthroquinones and phenols were estimated [10-19].

\section{Isolation of active constitutes}

Isolation of pure components involved the following steps:Chromatographic separation using silica gel $(100-200 \mathrm{mesh})$. The extract $(10 \mathrm{~g})$ was chromatographed over silica gel $(100-200)$ mesh on column $55 \mathrm{~cm}$ length and $6 \mathrm{~cm}$ diameter. Elution was carried out with solvent mixture of increasing polarities. Fractions were collected in $100 \mathrm{ml}$ portions and monitored by TLC (silica gel ' $\mathrm{G}$ ' as adsorbent) and the fraction showing similar spots are pooled together. Elution with ethyl acetate: ethanol(EA:Et-OH :(40:60) gave brown crystalline solid $(450 \mathrm{mg})$ and named as C.Odorata1. Similarly,elution with EA:Et-OH (50:50) yielded shiny brown coloured gel $(100 \mathrm{mg})$ and was designed as C.Odorata2.

\section{Experimental Animals}

Swiss Albino Mice of either sex were used for the study. The animals were kept at $27^{\circ} \pm 2^{\circ} \mathrm{C}$, Relative humidity $44-56 \%$ and light and dark cycles of 10 and $14 \mathrm{hr}$, respectively, for 1 week before and during the experiments. Animals were provided with water ad.libitum and standard diet and the food was withdrawn 18-24 $\mathrm{hr}$ before the start of the experiment.

\section{Acute Toxicity Study}

Acute toxicity study was performed on Swiss Albino Mice and the animal were kept fasting for overnight providing water and libitum, after which the extracts were administered orally and observed the mortality of animals. The activity was performed as per CPCSEA guide lines.

\section{Skeletal muscle relaxant property \\ Rota rod apparatus}

Rota rod is a horizontal metal rod coated with rubber, $3 \mathrm{~cm}$ in diameter, put at a rotation of $25 \mathrm{rpm}$. The metal rod is about $50 \mathrm{~cm}$ above the surface to prevent the animal from jumping off the roller. The mice were placed on the revolving rod. The initial basal reading of the number of rotations covered by each animal before falling from the rota rod was recorded. The test and standard compound was administered $1 \mathrm{hr}$ before placing the rats on the rota rod. The number of animals falling from the rota rod during this period was counted. The animals falling from the rota rod within the test period was calculated for every test and standard drug concentrations and compared [20].

Mice were divided into 4 groups consisting of 6 animals each.

Group I (Control): Received normal saline ( $1 \mathrm{ml} / \mathrm{kg}$ body weight).

Group II (Standard): Received diazepam ( $4 \mathrm{mg} / \mathrm{kg}$ body weight).

Group III Received Ethanol extract of C.Odorata ( $50 \mathrm{mg} / \mathrm{kg}$ body weight).

Group IV Received Ethanol extract of C.Odorata (100 mg/kg body weight).

Statistical Significance: The results of the study were expressed as mean \pm SEM, $n=6$. ANOVA) followed by Tukey-Kramer Multiple Comparisons.

\section{RESULTS}

Preliminary phytochemical screening revealed the presence of proteins, carbohydrates, saponins, glycosides, steroids, triterpenes, flavonoids, tannins and phenolic compounds. 
Table (1) showing phytochemical constituents of EEDR Extracts

\begin{tabular}{|c|c|c|c|c|}
\hline SL.No & Extract & Consistence & Yield(gm) & Constituent \\
\hline 1. & Petroleum ether & Solid & 10 & Saponin glycosides, fixed oil, fat \\
\hline 2. & Chloroform & gel & 7 & protein, amino acids, fatty acids \\
\hline 3. & Ethanol & gel & 20 & Phenol, tanins, Phenols, flavonides, Alkolodes \\
\hline
\end{tabular}

\section{Acute Toxicity Study}

During acute toxicity studies, EECO (1000 mg/kg body weight) neither produced any abnormal effect nor moribund stages no death was observed.

\section{Skeletal muscle relaxant activity}

Rota rod apparatus

Skeletal muscle relaxant activity In the case of rota rod, it was observed that the (EECO) at a dose of 50 and 100 (mg/kg body weight) showed good Skeletal muscle relaxant activity when compared to control.

Table (2) showing the activity of EECO Extract on Skeletal muscle relaxant property by using Rota rod Apparatus

\begin{tabular}{|c|c|c|c|c|c|}
\hline SL.No & $\begin{array}{c}\text { Treatment } \\
\text { Groups }\end{array}$ & \multicolumn{2}{|c|}{ Fall of Time in seconds } & \multicolumn{2}{c|}{$\begin{array}{c}\text { Difference } \\
\text { Percentage } \\
(\%)\end{array}$} \\
\cline { 3 - 5 } & Control & $254.166 \pm 11.577$ & - & - \\
\hline 1 & $\begin{array}{c}\text { Standard } \\
\text { diazepam } \\
(4 \mathrm{mg} / \mathrm{kg} ., \mathrm{i} . \mathrm{p})\end{array}$ & $254.166 \pm 11.577$ & $28.833 \pm 0.8333$ & $225.333 \pm 10.743$ & \\
\hline 2 & $50 \mathrm{mg}$ & $254.166 \pm 11.577$ & $85.833 \pm 6.822$ & $168.333 \pm 4.757$ & $66.22 \%$ \\
\hline 3 & $100 \mathrm{mg}$ & $256.166 \pm 10.904$ & $73.833 \pm 5.480$ & $182.333 \pm 5.422$ & $71.17 \%$ \\
\hline 4 & & & & & \\
\end{tabular}

Data was analysed using one way ANOVA followed by pairwise comparison.

Values are expressed as mean \pm S.E.M. $n=6, * * * \mathrm{P}<0.001 \mathrm{HS}$

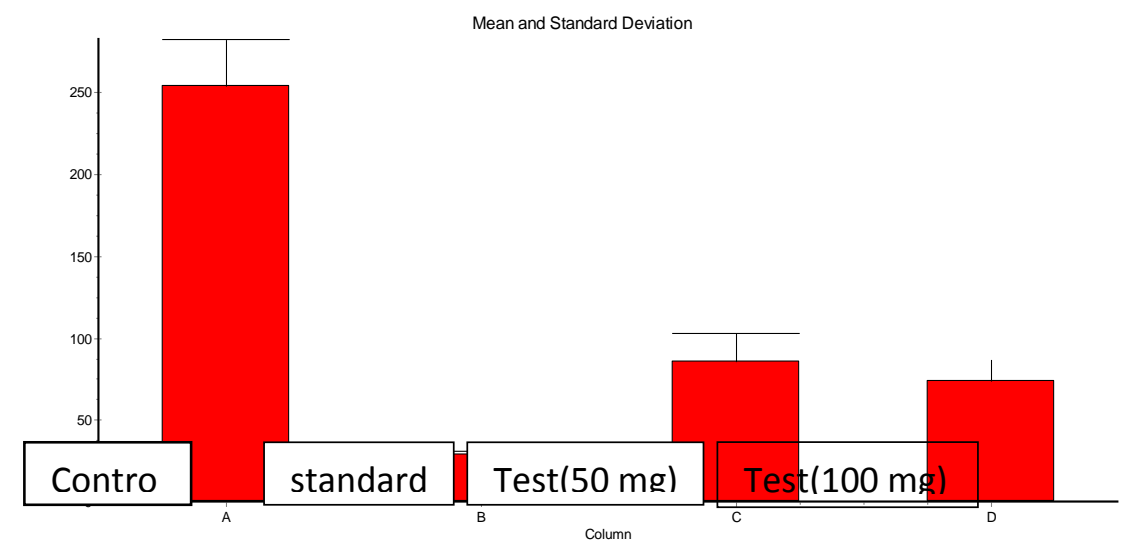

Figure:showing the activity of EECO Extract on Skeletal muscle relaxant property by using Rota rod Apparatus

\section{DISCUSSION}

In the present study the test samples of leaf extract of Chromoleana odorata belongs to the family Asteraceae were tested for skeletal muscle relaxant activity. Several reports are available on many plant species belonging to the same family exhibit skeletal muscle relaxant activity so the plant is presently studied [21, 22]. In this study, fall off time and muscle grip were taken as a measure of skeletal muscle relaxant activity. Diazepam showed significant neuromuscular blocking action. In the present study test samples exhibited significant $(\mathrm{P}<0.001)$ skeletal muscle relaxant activity at a dose of $50 \mathrm{mg} / \mathrm{kg}$ body weight and $100 \mathrm{mg} / \mathrm{kg}$ body weight. Among these test samples Ethanol leaf extract at dose of $100 \mathrm{mg} / \mathrm{kg}$ body weightexhibited more neuromuscular blocking action. It may be due to the presence of alkaloids, Phenols, Mucilage, carbohydrates, glycosides, saponins and flavonides. 


\section{CONCLUSION}

It can be concluded from the study that the skeletal muscle relaxant activity of the ethanol extract of Chromoleana odorata may be via non-specific mechanisms. However, extensive studies are needed to evaluate the precise mechanism(s), active principles and the safety profile of the plant as a medicinal remedy for musculoskeletal disorders.

\section{REFERENCE}

[1] Kalakonda R, Kadiri SK. Screening of skeletal muscle relaxant activity of plant Vicia Faba. International Journal of Pharmacy. 2013; 4: 237-240.

[2] Brunton L L, Blumenthal D K, Murri N, Dandan R H, Knollmann B C. Goodman \& Gilman's The Pharmacological Basis of Therapeutics. 12th Ed. New York: McGraw-Hill, 2011.

[3] Sangha R. Bijekar1, M.C. Gayatri2, L. Rajanna2 International Journal of innovative Research in science, Engineering and technology K.C. Sahni, "The book of Indian tree". 2nd edition Himalays Publishing House, 2009; 285-289

[4] R. Wantana, N. Tassanee, S. Sanan, "Antipyretic, anti-inflammatory and analgesic activity of Putranjiva roxburghii leaves”, Net Med (Tokyo). 2009; 63(3): 290-296.

[5] Singh and N. K. Dubey, "An ethnobotanical study of medicinal plants in Sonebhadra District of Uttar, Pradesh, India with reference to their infection by foliar fungi" Journal of Medicinal Plants Research, 2013; 6(14): 2727-2746.

[6] Rupesh Maurya and Nitin Dongarwar, "Studies on the medicinal uses of wild trees of Nagpur district", International Journal of life science and Pharma Research, 2012; 2(1): 21-25.

[7] R.D. Gibbs, "Chemotaxonomy of Flowering Plants", McGill Queen's University Press, Montreal and London, 1974; 1.

[8] O.O. Aiyelaagbe and M.Paul Osamudiamen, "Phytochemical Screening for Active Compounds in Mangifera indica Leaves from Ibadan", Oyo State, 2009; 2(1): 11-13.

[9] B.D.H. El-Tawil, "Chemical constituents of indigenous plants used in Native Medicines of Saudi Arabia, II" Arab Gulf J Sci Res A., 1983; 1(12): 395 -410

[10] . R. Chandrashekar and S.N. Rao, "Phytochemical analysis of ethanolic extract of leaves of leucas indica (eelli)" Int J Pharm Bio Sci. 2013; 4(1): 33 - 38.

[11] K.R. Brain and T.D. Turner, "The practical evaluation of phytochemicals", Wright Science Technical: Bristol, 1975.

[12] P. Tiwari, B. Kumar, M. Kaur, G. Kaur, H. Kaur, "Phytochemical screening and extraction: A review", Internationale Pharmaceutica Sciencia, 2011; 1(1): 98-106.

[13] 13. Veena Sharma, Aastha Agarwal, Urmila Chaudhary, Manu Singh, "Phytochemical investigation of various extracts of leaves and stems of Achyranthes aspera Linn," International Journal of Pharmacy and Pharmaceutical Sciences, 2013; 5 .

[14] 14. D. Sai Koteswar Sarma and A. Venkata Suresh Babu, "Pharmacognostic and phytochemical studies of Thespesia populnea Linn,” J. Chem. Pharm. Res. 2011; 3(4): 237-244.

[15] Saxena Mamta and Saxena Jyoti, "Phytochemical screening of Acorus Calamus and Lantana Camara", International research Journal of Pharmacy, 2012; 3(5): 323-326.

[16] Odebiyi and A.E. Sofowora, "Phytochemical screening of Nigeria medicinal plant", part III Lioydia, 1978; 4: 234-246.

[17] Seema Firdouse, Parwez Alam, "Phytochemical investigation of extract of Amorphophallus campanulatus tubers", International Journal of Phytomedicine, 2011; 3: 32-35.

[18] A. Sofowora, "Medicinal plants and traditional medicine in Africa", John Wiley, Chichester, 1982; 179.

[19] Hans Gerhard vogel, "Drug discovery and evaluation: pharmacological assays; 3rd edition, 1: 580-581.

[20] Hans Gerhard vogel, "Drug discovery and evaluation: pharmacological assays; 3rd edition, 1: 578-579.

[21] Nazar ul islam, Ibrahim khan, abdul rauf, naveed Muhammad, muhammed shahid and mohammad raza shah, "Antinociceptive, muscle relaxant and sedative activities of Euporbia milii". G-BMC complement Altern med, 2015; 15: 160.

[22] Sudharshan et. al. "Central nervous system (CNS) depressant\& analgesic activity of methonolic extract of drypetes roxburgii wall in experimental animal model". Research journal of pharmacy\& technology. 2009; 2(9): 854-857. 